\title{
REGIONAL DISPARITIES IN SLOVAKIA \\ IN TERMS OF DEMOGRAPHIC INDICATORS
}

DOI: http://dx.doi.org/10.18509/GBP.2015.49

UDC:314.117(437.6),,1996/2013“6

RNDr. Gabriela Repaská, PhD.

RNDr. Katarína Vilinová, PhD.

RNDr. Jana Némethová, PhD.

Doc. RNDr. Alena Dubcová, CSc.

Constantine the Philosopher University in Nitra, Faculty of Natural Sciences, Department of Geography and Regional Development, Slovakia

\begin{abstract}
Regional disparities represent a set of inequalities between regions in natural, economic, social area, etc. In the paper, we study the regional disparities of Slovakia with the use of selected demographic indicators (natality, mortality, marriage, divorce, abortion, emigration, immigration of population, and age groups) for the period of $1996-2013$. The aim of paper is with the help of cluster analysis, we created the regional typology of demographic inequality which result is to point to the demographic spatial disparities in Slovakia. In the paper, will use the method of analysis and synthesis as well as graphical, mathematical-statistical, and cartographic methods.
\end{abstract}

KEYWORDS: regional disparities, demographic indicators, cluster analysis, typology of districts, Slovakia

\section{INTRODUCTION}

Population is a significant social capital of each region. Therefore, the socio-economic development of regions depends mainly on the quality of human resources in the regions, which also influence the changes in the country [11]. Most indicators of regional development and results of regional policy reflect population behavior in various areas of social life. There are significant differences between individual regions of Slovakia in terms of their population situation; it reflects in unemployment [7]. In Slovakia, we can see mainly a significant west-east polarization. There is also a strong north-south polarization in population-demographic situation where especially southern districts are the most problematic regarding population. The aim of the paper is to highlight the demographic spatial non-uniformity Slovak regions using selected demographic indicators and cluster analysis in order to establish their regional typology.

\section{THEORETICAL AND METHODOLOGICAL BASIS}

In recent years, the professional literature devotes an intense attention to regional disparities at different hierarchical levels of the EU countries and also within the individual countries inter-regional inequalities are being studied. According to [9] the regional disparities began to be manifested in Slovakia during the transition period to a market mechanism as well as by changing social and economic environment. [4] claims that the main cause of deepening regional differences are different possibilities of regions to adapt to the requirements of economic and social transformation and thus to the developmental conditions. The overall picture of regional differentiation in Slovakia is characterized by polarization while the worst indicators can be seen in the southern part 
of Central Slovakia and northeast regions of Slovakia [2]. According to [6], regional disparities are characterized as the ability to adapt to economic and social change or it is the result of a differentiated state of the factors which condition the development of the region by varying degree. The main causes of the differentiated regional development in Slovakia are considered to be the primary potential of the area, structure of the residential network, macro-position attractiveness and economic specialization of regions. According to [8] the regional disparities are the differences in the socio-economic development of regions which are the result of their non-uniformity.

Regional disparities of selected demographic phenomena in the European Union are addressed by [3]. Their basic analytical tools are Theil index and Gini coefficient. These authors studied several demographic indicators such as the total fertility rate, life expectancy, infant mortality rate, average age, and the proportion of university graduates at the hierarchical level of NUTS II. [5] presents the results of research focused on spatial differentiated disparities of the districts of the Czech Republic based on the quality of human resources. The research was carried out on the basis of a statistical method of cluster analysis with the help of 24 demographic indicators.

In this paper, the regional disparities in Slovakia were studied with the use of the following demographic indicators - natality, mortality, marriage rate, divorce, abortion, immigration, emigration, and age categories according to the EU classification (preproductive age $0-14$, productive age 15-64, post-productive age $65+$ ) for the periods of 1996-2004 and 2005-2013. Statistical databases were obtained from the Statistical Office of the Slovak Republic [10] and interpreted with the use of the ArcGIS 10.1 software. For the qualitative representation of regional disparities through demographic indicators in Slovakia, we used the mathematical method of hierarchical cluster analysis applied for the period of 1996-2013. For the calculation of the distance rate, expressing the similarity of districts, we used the Euclidean distance. The graphical representation of a clustering procedure is a dendrogram which included the districts of Slovakia into clusters.

\section{ANALYSIS OF SELECTED DEMOGRAPHIC INDICATORS IN SLOVAKIA IN THE PERIOD OF 1996-2004 AND 2005-2013}

In recent years, the development of population phenomena in Slovakia attracts attention of not only scientific disciplines, but also the attention of institutions of social practice as well as the general public.

The first assessed demographic indicators are basic components of natural change of population - natality and mortality. They are cross-cutting indicators that are affected by a variety of socio-economic factors. Natality is considered a key process of demographic development and overall development of the society [1]. In Slovakia, we can see a downward trend of natality and growing trend of mortality in the studied period of 20052013 compared to the period of 1996-2004. The highest natality is typical for the districts of Eastern and Northern Slovakia (Fig. 1). An interesting fact can be considered the increase of natality in the districts of Bratislava in the period of 2005-2013 which may be affected especially by migration of younger age categories of the population from east to west. In terms of mortality, the districts of Eastern Slovakia recorded the lowest values which is caused mainly by a higher proportion of population in pre-productive age, comparing to other regions of Slovakia, and a significant proportion of Roma population. Conversely, the increased population mortality is linked to the southern agricultural areas with aging population. 

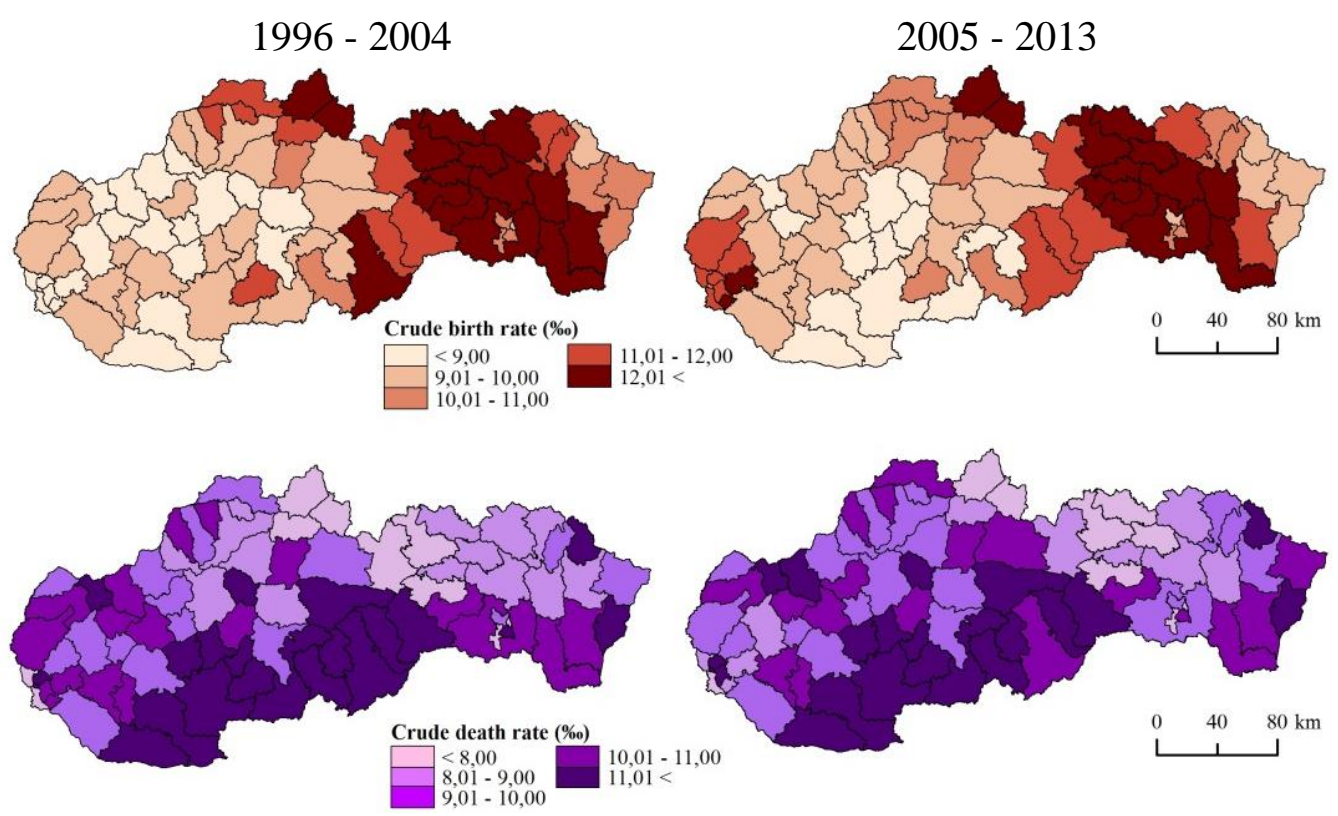

Fig. 1. Natality and mortality of the Slovak population in the period of $1996-2004$ and $2005-2013$.

Marriage rate is of crucial importance in family behavior of the population as well as in the whole reproductive process because the marriage forms a family. In the studied period of 2005-2013 there was an increase in marriage rate in the districts of Slovakia which is strongest in the eastern part of the country. The apparent increase can be seen also in the Bratislava Self-governing Region and in the districts of Northern Slovakia which are characterized with stronger religiosity (Fig. 2).

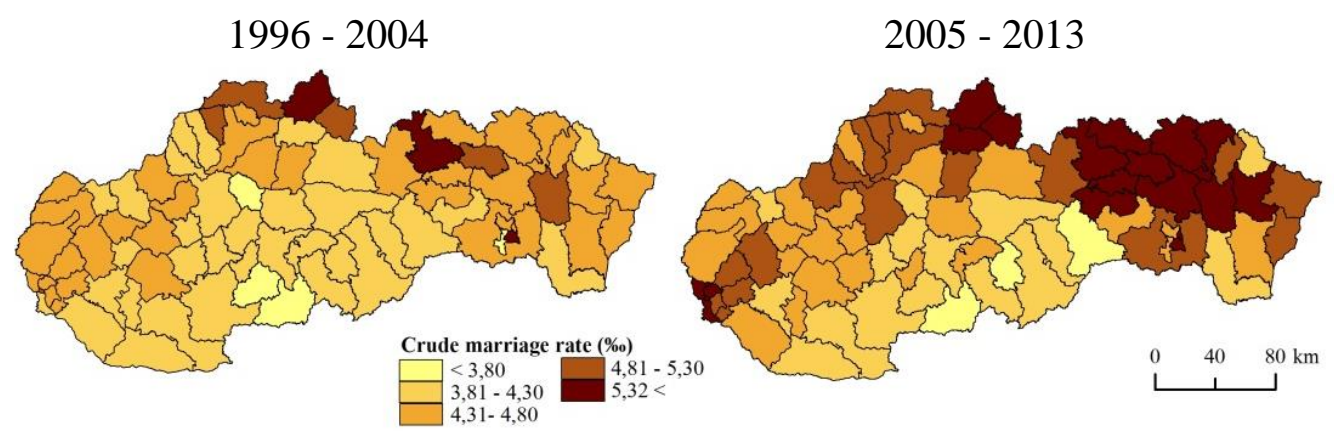

Fig. 2. Marriage rate of the Slovak population in the period of 1996 - 2004 and 2005 - 2013.

Divorce is a negative demographic phenomenon in terms of forming a family and in terms of population reproduction. In the districts of Slovakia, when comparing the two studied periods, we can see the growth of divorce rate while the lower divorce rate remains lower in the districts of Northern Slovakia (Fig. 2). Regarding abortion, which significantly affects natality and generally also population health status, we can see a downward trend. In the period of 2005-2013, the more positive situation is evident compared to the previous period of 1996-2004. The abortion in districts of Bratislava I-IV significantly decreased as well as in the districts of Central Slovakia (Fig. 3). 


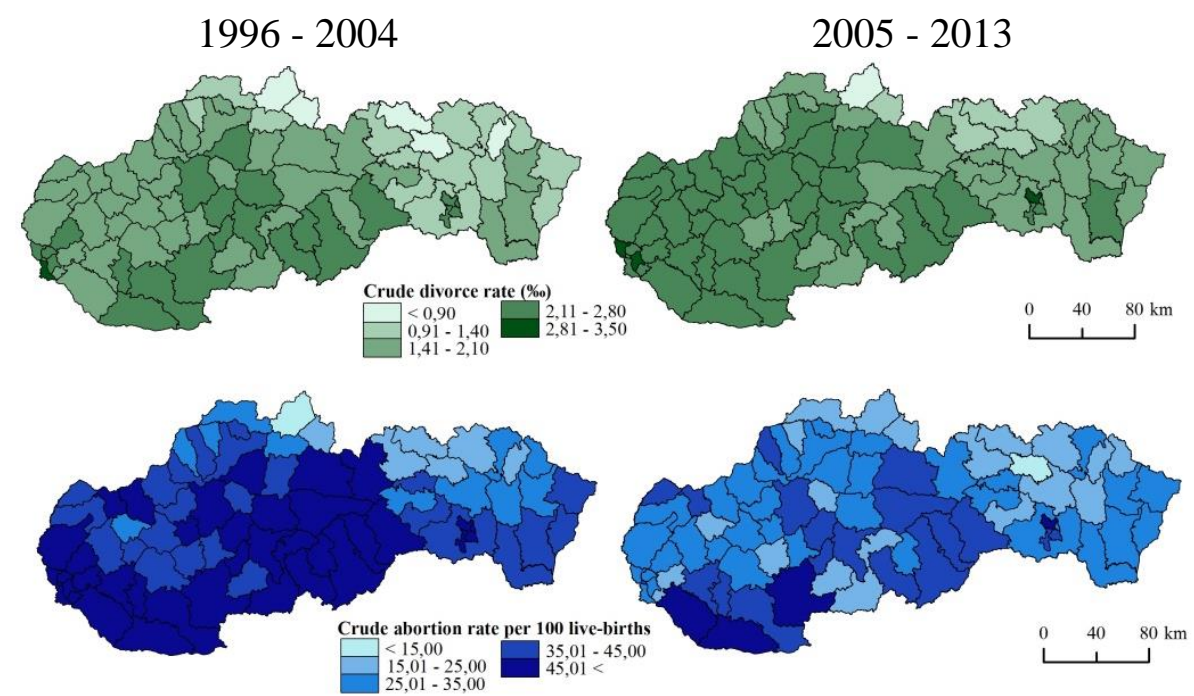

Fig. 3. Divorce and abortion of the Slovak population in the period of $1996-2004$ and $2005-2013$.

Important demographic variables affecting the demographic development of the population as well as regional development of the territory are also components of the migration change of population - emigration and immigration. The intensity of immigration and emigration in Slovakia is the biggest in the districts of the Bratislava and Košice Self-governing Region. The high migration turnover in these regions is mainly due to proximity of the two big cities of Bratislava and Košice where urbanization and suburbanization processes are currently ongoing. When comparing the two periods, only in the case of immigration it is possible to see more significant changes mainly in Central and Eastern Slovakia. The intensity of emigration in Slovakia is relatively stable (Fig. 4).

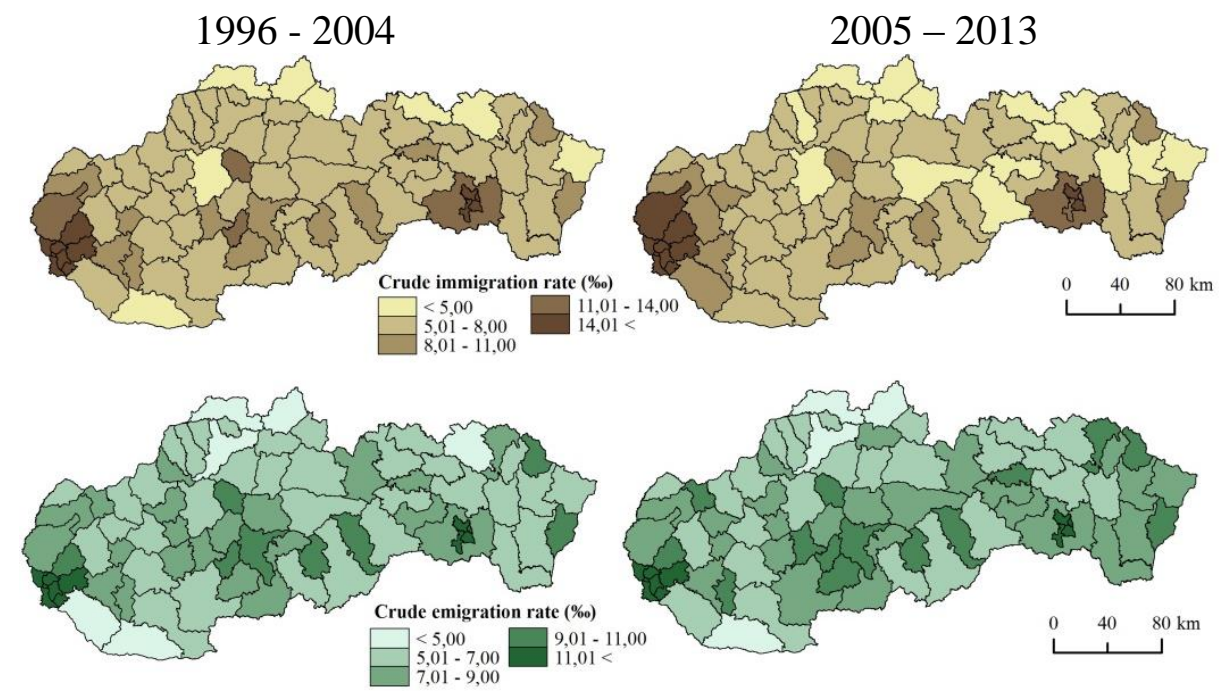

Fig. 4. Immigration and emigration of the Slovak population in the period of 1996 - 2004 and 2005 - 2013.

The age structure of the population can be assessed through productive, reproductive, main age groups, aging index, average age, age index, age pyramid, etc. The set of methods and techniques is very different, however, these files contain several statistical and graphical methods that are different in availability of data. The productive age groups are often applied according to the classification of the European Union. It is the preproductive age (up to 14 years), productive age (15-64 years), and post-productive age 
(65 and more). In Slovakia based on the productive age groups, we can see significant regional disparities in both studied periods. The highest values of pre-productive age are recorded in the districts of Eastern Slovakia and lowest values in the districts of Central and Western Slovakia which are, contrary, dominated by post-productive age groups. During the period of 2005-2013, the pre-productive age groups markedly decreased compared to the period of 1996-2004 at the expense of productive and post-age population (Fig. 5).

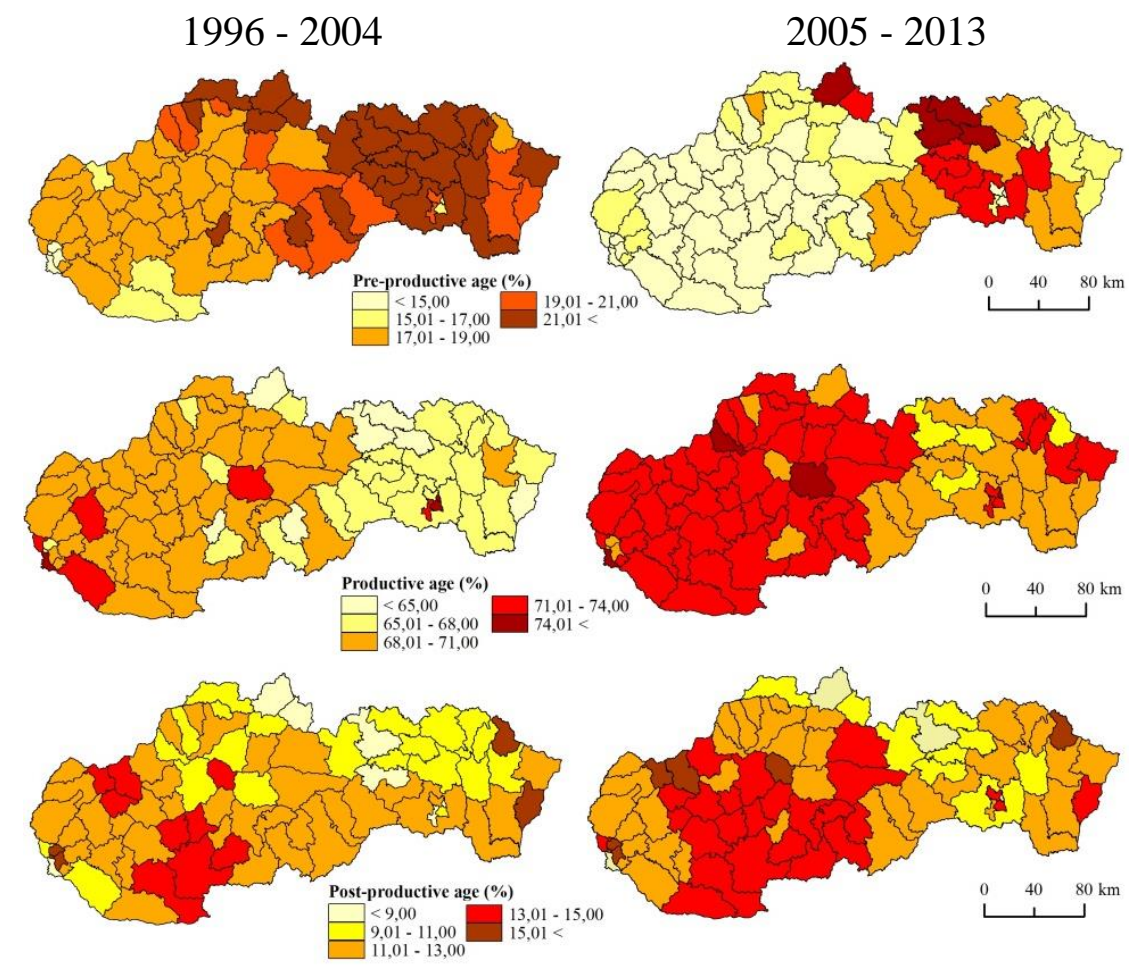

Fig. 5. Age groups of the Slovak population in the period of 1996 - 2004 and 2005 - 2013.

\section{TYPOLOGY OF SLOVAK DISTRICTS ACCORDING TO SELECTED DEMOGRAPHIC INDICATORS IN THE PERIOD OF 1996-2013}

Demographic indicators, which were characterized in previous analyses, were further transformed into the so-called dendrogram with the use of cluster method which based on the similarity of selected demographic indicators combined the districts of Slovakia into clusters (Fig. 6). Because of the number of the created clusters, the most appropriate joint distance was selected the distance 4 as the basis for the created typology of districts according to demographic indicators. After creating the individual clusters, the types of regions in Slovakia were formed according to the studied demographic indicators. Selected demographic indicators were, in terms of demographic development, classified into a group of positive and negative indicators. The group of positive demographic indicators included the natality, immigration, marriage rate, pre-productive and productive age groups. The negative demographic indicators contained mortality, emigration, divorce, abortion and post-productive age group. 


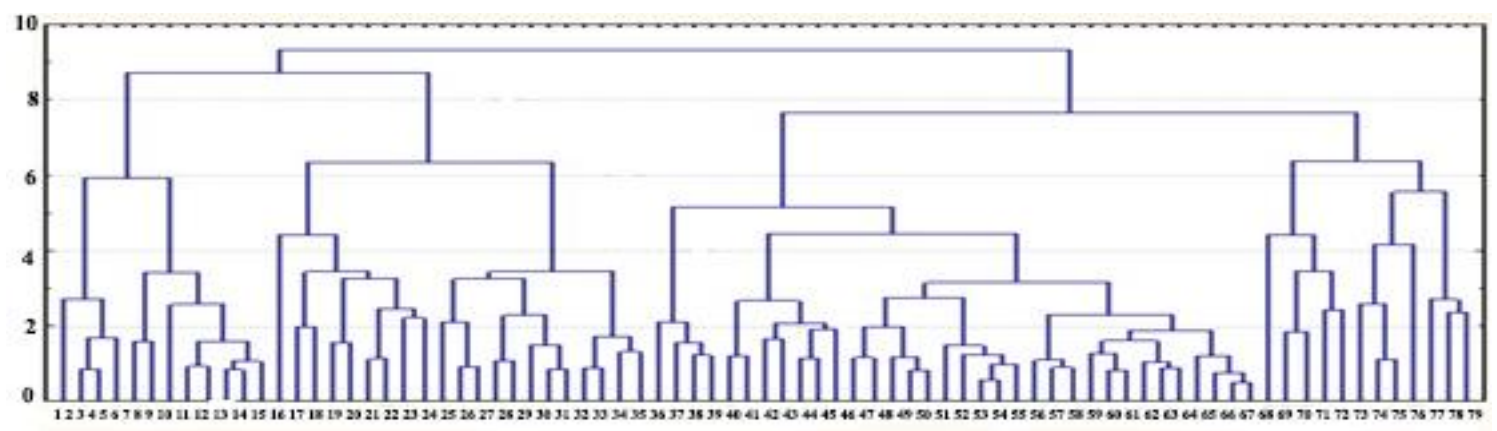

1-KK, 2-SL, 3-SB, 4-NO, 5-GL, 6-LE, 7-TS, 8-KM, 9-DK, 10-SK, 11-SP, 12-BY, 13-PO, 14-SN, 15-KS, 16-VT, 17-BJ, 18-TV, 19-MI, 20-PP, 21CA, 22- NZ, 23-LV, 24-KN, 25-ZA, 26-NR, 27-PD, 28-TN, 29-TT, 30-BB, 31-MT, 32-GA, 33-DS, 34-RA, 35-RS, 36-RV, 37-LC, 38-SO, 39-ML, 40-KA, 41-BS, 42-VK, 43-PT, 44-TR, 45-BR, 46-LM, 47-ZV, 48-ZH, 49-SA, 50-PE, 51-ZM, 52-ZC, 53-DT, 54-MY, 55-NM, 56-TO, 57-PN, 58HE, 59-PB, 60-IL, 61-SI, 62-RK, 63-SE, 64-SV, 65-PU, 66-BN, 67-HC, 68-KE3, 69-KE2, 70-KE1, 71-BA5, 72-BA4, 73-SC, 74-PK, 75-MA, 76BA2, 77-KE4, 78-BA3, 79-BA1

Fig. 6. Dendrogram for typology of the districts in Slovakia.

This led to the creation of 10 types of regions forming a typology of demographic nonuniformity of Slovakia (Fig. 6). The positive demographic regions are types A - F and on the contrary, the regions in the types of $\mathrm{G}$ - I belong to demographically unstable or negative regions.

The type A includes 5 districts located in the northern part of Slovakia. These are the districts (Námestovo, Tvrdošín, Kežmarok, Stará Lubovňa, Sabinov) where values of 9 studied indicators indicate a positive demographic development of these areas. Only low immigration has an adverse effect on the development. Similarly, the type B is less numerous. It consists of only four districts. The district of Čadca in the north of the country and in the east there are the districts of Spišská Nová Ves, Bardejov, and Vranov nad Topl'ou. Several studied indicators (8) positively affects the demographic development of the districts e.g. high natality, low mortality, high marriage rate, low divorce rate. Negative issues in the development of the mentioned districts were low immigration and high post-productive age of population.

The type $\mathrm{C}$ consists of 6 districts occurring as scattered in Slovakia. In the north of Slovakia, it is the district of Bytča and Dolný Kubín, in the east of Slovakia - districts of Svidník, Stropkov, Levoča, and Gelnica. These districts are characterized by 8 indicators which values has a positive impact on demographic development. Similarly as in the type $\mathrm{B}$, adversely effects in the development are low immigration (below the Slovak average) and also the low number of population in productive age. This indicator affected the inclusion of the districts into the type $\mathrm{C}$ and $\mathrm{B}$ in which the number of inhabitants in productive age occurs above the average of Slovakia. Districts belonging to the type $\mathrm{D}(8$ districts) are scattered across the whole country while the concentration of 4 districts is in the Central Slovakia (Banská Štiavnica, Krupina, Vel'ký Krtíš, and Poltár). In this type the adverse effects on demographic development are only low immigration and low representation of population in the pre-productive and productive age. The values of the other studied indicators (7) suggest a positive demographic development of these areas. The type $\mathrm{E}$ is, in terms of spatial units, the most numerous. It consists of 27 districts forming almost continuous region in the northern part of Western Slovakia (e.g. districts of Piešt'any, Hlohovec, Topol'čany, Partizánske, Bánovce nad Bebravou) and also in the central and southern part of Slovakia (e.g. Žiar nad Hronom, Zvolen, Detva, Lučenec, Revúca, Rožňava). In this type the positive (e.g. low mortality, high immigration, high marriage rate) and negative (e.g. low natality, high emigration, high divorce rate) indicators of demographic development are equally represented (5). Similarly as the type $\mathrm{E}$, also the type $\mathrm{F}$ is characterized by the same number of indicators - 5 affecting positively 
and negatively at the same time at the demographic development of the area. This type included 7 districts which are mostly located in the Eastern Slovakia. The fact that the districts were included to the type $\mathrm{F}$ instead of the previous type $\mathrm{E}$ was affected by low immigration, which is high in the type E, that is above the average of Slovakia. The positive development of the districts in this type is indicated by the low mortality, low emigration, high marriage rate, high number of population in pre- and post-productive age.

The type $\mathrm{G}$ and also other types $\mathrm{H}, \mathrm{CH}$ and I indicate the negative demographic development of districts included in these types. In these types, indicators adversely affecting demographics are dominant. The type $\mathrm{G}$ included only the urban districts of Bratislava - Bratislava I and V and Košice - I, II, and III. The positive demographic development of these districts is supported in particular by the low mortality and high immigration of population. Besides these, it is also the high marriage rate above the average of Slovakia and the low number of population in post-productive age. In the type $\mathrm{H}$, the negative demographic trend is indicated particularly by low immigration, low marriage rate, but also e.g. low natality and high mortality of population. This type is spread in the western part of Slovakia in the districts e.g. Komárno, Dunajská Streda, Trnava, Nitra and also in districts of the northern part of Slovakia (Žilina, Martin, Považská Bystrica). This type includes a total of 10 districts. The positive effect on demographic trend can be seen in the below average values of Slovakia in indicators emigration, divorce, abortion, and post-productive age. The type $\mathrm{CH}$ contains 5 districts located only in Western Slovakia. They are the urban districts of Bratislava II, IV and other districts of Malacky, Pezinok, and Senec. Similarly as other urban districts in the type $\mathrm{G}$, the positive effect on demographics is in the high immigration, high marriage rate and low post-productive age of population. The last type I includes only the district of Košice IV. This urban district is characterized by high immigration of population as well as the low divorce and abortion rate (Fig. 7).

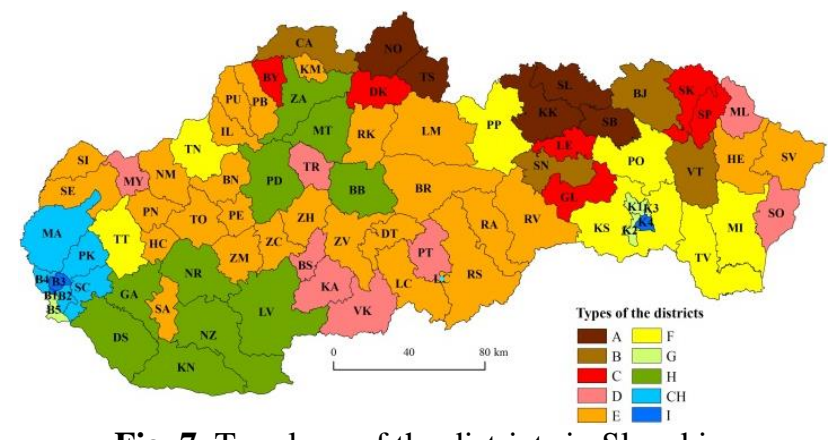

Fig. 7. Typology of the districts in Slovakia.

\section{CONCLUSION}

Based on the results of the qualitative evaluation of human resources by means of cluster analysis, it is possible to identify 10 types of regions (clusters) in Slovakia. By them, we created the typology of regions of Slovakia resulting from demographic indicators and thus demonstrating their regional disparities. The positive demographic trend is indicated by 6 types of regions (type A - F), which out of the total number of districts, accounted for $75 \%$. The remaining $25 \%$ of districts in Slovakia is characterized by negative demographic trend which is shown by 4 types of regions (G - I). Based on the mentioned, we can conclude that most of the districts of Slovakia is characterized by the positive progressive demographic trend i.e. economically less developed districts. These districts 
are located mainly in the Eastern (excluding districts of Košice I - IV), Northern, and Central parts of Slovakia (excluding districts of Prievidza, Martin, Žilina, Banská Bystrica). The South-western and Western part of Slovakia is specific by an adverse depopulative demographic trend which is characteristic for the districts of Bratislava Selfgoverning Region and southern agricultural districts of the Nitra and Trnava Selfgoverning Regions, where begins the poverty zone of Slovakia [12]. Stationary demographic development is characteristic for southern districts of Eastern Slovakia which are supplemented mainly by the districts of the Banská Bystrica and Trenčín Selfgoverning Regions.

The paper was elaborated within the projects: UGA Geographical Visualization of Cancers on the Example of the Nitra Self-governing Region and UGA VII/24/2014 Suburban Processes in the Urban parts of the Nitra City.

\section{REFERENCES}

[1] Bleha, B. Lokálny demografický vývoj na Slovensku: percepcia, spoločenské implikácie a interdisciplinárne výzvy, Sociológia, Slovakia, 2011, vol. 43, pp 362-390.

[2] Bucher, S. Regionálne disparity na Slovensku vo svetle socioekonomických ukazovatel'ov, XVII. mezinárodní kolokvium o regionálních vědách - sborník příspěvků, Czech Republic, 2014, pp 95-105.

[3] Durček, P. \& Bleha, B. Regionálna nerovnomernost' vybraných demografických javov v Európskej únii, Geografický časopis, Slovakia, 2013, vol. 65, pp 3-22.

[4] Gajdoš, P. Vývoj regionálnych disparít na Slovensku - málo rozvinuté regióny, Životné prostredie, Slovakia, 2008, vol. 42, pp 21-27.

[5] Hübelová, D. Hodnocení lidských zdrojů v demografickém kontextu-vybrané výsledky shlukové analýzy okresů České republiky, XVII. mezinárodní kolokvium o regionálních vědách, Czech Republic, 2014, pp 224-230.

[6] Korec, P. Regionálny rozvoj Slovenska v rokoch 1989 - 2004, Geografika, Slovakia, p 227.

[7] Kramáreková, H. Vývoj nezamestnanosti v obciach Nitrianskeho kraja v rokoch 2001 a 2005, Geografické informácie 11, Slovakia, 2007, pp 272-284.

[8] Matlovič, R. \& Matlovičová, K. Regionálne disparity a ich riešenie na Slovensku v rozličných kontextoch, Folia geographica, Slovakia, 2011, vol. 18, pp 8-87.

[9] Rajčáková, E. \& Švecová, A. Regionálne disparity v kontexte regionálnej politiky v SR, XIII. mezinárodní kolokvium o regionálních vědách - sborník příspěvků. Czech Republic, 2010, pp 33-41.

[10] Statistical Office of the Slovak Republic (www.statistics.sk).

[11] Vojtek, M. Súčasná krajinná štruktúra povodia Vyčomy, Geografické štúdie, Slovakia, 2012, vol. 16, pp 75-85.

[12] Veselovský, J. \& Šolcová, L. Demografický aspekt chudoby v obciach Nitrianskeho kraja, Geografické poznatky bez hraníc, Slovakia, 2010, pp 145-154. 